\title{
Prospective study of association of uterine atonicity and serum calcium levels
}

\author{
Premalahta HL*, Raghupathi Krishnegowda
}

Department of Obstetrics and Gynaecology, Hassan Institute of Medical Sciences Hassan, Karnataka-573201, India

Received: 29 April 2016

Revised: 07 June 2016

Accepted: 09 June 2016

\section{*Correspondence:}

Dr. Premalahta HL,

E-mail: premalatha.gowda@yahoo.in

Copyright: ( $)$ the author(s), publisher and licensee Medip Academy. This is an open-access article distributed under the terms of the Creative Commons Attribution Non-Commercial License, which permits unrestricted non-commercial use, distribution, and reproduction in any medium, provided the original work is properly cited.

\section{ABSTRACT}

Background: Uterine atony is one of the leading causes of maternal morbidity and mortality. Uterine atony and PPH is a life threatening condition. The oxytocic drugs increase uterine tone by increasing intracellular calcium. Optimum levels of calcium are very important for the effective uterine contraction. Objective of this study was to correlate the serum calcium levels and uterine atonicity and PPH in women admitted in $1^{\text {st }}$ and $2^{\text {nd }}$ stage of labor in tertiary care hospital like Sri Chamarajendra hospital Hassan institute of medical sciences, Karnataka, India.

Methods: Study design is case control study in department of OBG Sri Chamarajendra hospital Hassan. Duration of study is from July 2014 to 2015 . Number of subjects studied 200 groups A with serum calcium less than $8 \mathrm{mg} \%$ and uterine atony. Group B with serum calcium between $8-10.4 \mathrm{mg} \%$ and uterine atony, after vaginal delivery or caesarian delivery. Features of atonicity: soft distended uterus with lack of muscle tone.

Results: Total 200 clients were studied. 100 clients with serum calcium $>8 \mathrm{mg} \%$ and 100 clients with serum calcium $<8 \mathrm{mg} \%$. In women with serum calcium $<8 \mathrm{mg} \%, 24$ patients developed uterine atonicity. In women with serum calcium $>8 \mathrm{mg} \%$ only one client developed uterine atonicity.

Conclusions: Our result revealed that low calcium level is strongly associated with uterine atony, hence is a risk factor for uterine atony.

Keywords: Serum calcium, Uterine atony, $\mathrm{PPH}$

\section{INTRODUCTION}

Uterine atony is one of the commonest cause of PPH leading to maternal morbidity and mortality. ${ }^{1,2} \mathrm{PPH}$ is unpredictable and rapid cause of maternal death. In $2 / 3^{\text {rd }}$ of women who develop PPH have none of the known riskfactors mentioned in the exclusion criteria. The oxytocic drugs increase the uterine tone by increasing intracellular calcium. ${ }^{3-5}$ Therefore optimum levels of calcium are very important for the effective uterine contractions. Calcium exerts its effect by activating the muscle proteins and causing effective uterine contraction. IV calcium gluconate can promote uterine contraction and plays a key role in preventing and treating PPH by increasing the tone of the uterus. ${ }^{6}$ Patients with $\mathrm{PPH}$ from atonic uterus that had not responded to the usual oxytocic's had responded well with IV calcium gluconate with marked hardening of uterus and lessening $\mathrm{PPH}^{7}$ Serum calcium status regulated by vitamin $\mathrm{D}$ plays a role in smooth muscle function in early labor. Higher serum calcium levels have been reported in pregnant women at the time of vaginal delivery as compared to term women who were not in labor and delivered by caesarian operation. ${ }^{8}$ Calcium supplementation before LSCS has been used to prevent and treat PPH due to atonicity of uterus. ${ }^{9}$ It was speculated that the higher serum calcium levels played a role in the mechanism of initiation of labor which is the result of adequate uterine smooth muscle contraction. ${ }^{10}$ Reduced serum calcium level may affect the contractility of uterine smooth muscle, may 
result in atonic uterus and $\mathrm{PPH}$. So present study is conducted to determine the association of serum calcium levels with uterine atony in a tertiary care hospital.

\section{METHODS}

This is a prospective case control study conducted in the department of obstetrics and gynecology Hassan institute of medical sciences from 2014 December. A total of 200 subjects were included in the study and blood was collected for serum calcium in $1^{\text {st }}$ and $2^{\text {nd }}$ stage of labor. And grouped as a including clients with serum calcium more than $8 \mathrm{mg} \%$ (100 clients). And group B with serum calcium less than $8 \mathrm{mg} \%$ (100 clients). In both the groups' uterine tone was assessed clinically after fulfilling the inclusion and exclusion criteria's.

\section{Inclusion criteria}

- $\quad 1^{\text {st }}$ and $2^{\text {nd }}$ gravidas

- Both vaginal and caesarian deliveries

- Those who have consented

\section{Exclusion criteria}

Factors which interfere with the ability of the uterus to contract.

- Multiparity

- Placenta previa

- Retainedplacenta

- Bigbaby

- Anemia

- Hypotention

- Traumatic pph

- Multiple pregnancies.

- Prolongedlabor

- Hydromnios

- Abruptioplacenta

- Mismanagement oflabor

- Gestationaldiabetes

- Uterineanomalies

- Bleeding disorders.

Cases of uterine atonicity were taken when the uterus was soft, distended, and lacking muscle tone, after delivery of the placenta following caesarian operation and vaginal delivery. Oral informed consent was taken from all clients and approval from institutional ethical committee was obtained. chi square test was applied to compare the atonicity in both the groups.

Serum calcium levels and atonicity were correlated.

\section{RESULTS}

Total 200 clients were studied. 100 clients with serum calcium $>8 \mathrm{mg} \%$ and 100 clients with serum calcium $<8$ $\mathrm{mg} \%$.in women with serum calcium $<8 \mathrm{mg} \%, 24$ patients developed uterine atonicity. In women with serum calcium $>8 \mathrm{mg} \%$ only one client developed uterine atonicity.

Table 1: Serum calcium level and number of patient with uterine atonicity.

\begin{tabular}{|llll|}
\hline $\begin{array}{l}\text { Serum ca } \\
\text { level }\end{array}$ & $\begin{array}{l}\text { Ut atonicity } \\
+\end{array}$ & $\begin{array}{l}\text { Uterine } \\
\text { atonicity absent }\end{array}$ & $\begin{array}{l}\text { Total } \\
>8 \mathrm{mg} \%\end{array}$ \\
\hline$<1$ & 99 & 100 \\
\hline$<8 \mathrm{mg} \%$ & 24 & 76 & 100 \\
\hline
\end{tabular}

Chi square test $\mathrm{X} 2=0.04(<0.05)$. That means uterine atony is more when serum calcium is $<8 \mathrm{mg} \%$, compared to serum calcium level $>8 \mathrm{mg} \%$ which is statistically significant.

\section{DISCUSSION}

In this study we have compared the levels of serum calcium levels and uterine atony and PPH, a life threatening condition which may lead to emergency hysterectomy.

This result suggests that optimum serum calcium level is essential for the effective uterine contractions and low serum calcium level may cause atonic uterus and PPH of variable degree. 24 patients with serum calcium levels less than $8 \mathrm{mg} \%$. Developed uterine atony and PPH. 19 subjects were treated with oxytocics and compression sutures. ${ }^{5}$ patients did not respond to routine oxytocics, were given IV calcium gluconate $10 \mathrm{ml}$ in $500 \mathrm{ml}$ ringer lactate.

Uterus became firmer harder and PPH controlled. In current study we are of the opinion that all subjects admitted in labor should be tested for serum calcium levels and if serum calcium is less than $8 \mathrm{mg} \%$ should be anticipated atonicity and iv calcium gluconate should be infused to prevent PPH and we suggest further studies to correlate the serum calcium and atonicity.

Uterotonic drugs oxytocin, prostaglandins increase the contraction of uterine smooth muscle by increasing intracellular calcium level. ${ }^{11,12}$ Currently treatment options of severe hemorrhage secondary to uterine atony begins with uterotonic agents (oxytocins, ergometrine, prostaglandins), compression suture, intra uterine balloon tamponade, pelvic devascularization techniques, vascular occlution, failure to achieve control of bleeding prompts aggressive procedures such as abdominal hysterectomy. ${ }^{13}$

Our study suggests more studies to know serum calcium level may be the reason for atonic uterus and administration of calcium gluconte IV may increase the tone of the uterus and prevent $\mathrm{PPH}$ and thereby preventing aggressive procedure like hysterectomy. Nifedipine, Mgso and calcium channel blockers used during delivery were reported tobe associated with uterine atony, suggesting that low serum calcium may be associated with uterine atony. ${ }^{4,13}$ 


\section{CONCLUSION}

Our result revealed that low calcium level is strongly associated with uterine atony, hence is a risk factor for uterine atony. Therefore we suggest all patients admitted in labor should be estimated serum calcium and those with serum calcium less than $8 \mathrm{mg} \%$ may be administered IV calcium gluconate in second stage or before LSCS, to prevent PPH and aggressive management like hysterectomy, and to decrease maternal morbidity and mortality.

Funding: No funding sources

Conflict of interest: None declared

Ethical approval: The study was approved by the Institutional Ethics Committee

\section{REFERENCES}

1. Breathnach F, Geary M. Uterine atony; definition, prevention, nonsurgical management and uterine tamponade, semin perinatal. 2009;33(2)82.

2. Changhua L, Huajiang W. Obstetric dept Xiang yang city hospital, Xiangyang 441021, china, Chinese journal of medicine guide IV calcium gluconate in the prevention of PPH; 2012.

3. Khan SM, Saeed M, Mustafa G, Durrani HD. Uterine atony; association of low serum vitamin D. professional med J. 2014;21(6):1117-21.

4. Wetta LA, Szychowski JM, Seals S, Melisa SM, Joseph RB, Alan TN. Risk factors for uterine atony $/ \mathrm{PPH}$ requiring treatment after vaginal delivery. American journal of obstetrics and gynaecology. 2013;209(1):51e1-51e6.

5. Balki M, Talati C, Carvalho J. Investigating the effect of extracellular calcium on oxytocin -induced human myometrial contractility in vitro. Clinical trials. Gov. Identifier NCT02274454, Samuel Lunenfeld Research Institute, Mount Sinai Hospital.

6. $\mathrm{Yu} \mathrm{H}$, Ling Y. Calcium supplementation before cesarean section in prevention and treatment for postpartum hemorrhage due to uterine inertia. Journal of Hainan Medical College. 2009;15(6):646-7.

7. Preventing $\mathrm{PPH}$ naturally/birth faith org/exercise/preventing PPH naturally 2010. Available at http://birthfaith.org/exercise/preventingpostpartum-hemorrhage-naturally.

8. Papandreou L, Charsiotis G, Seferiadis K, Thanasoulias NC, Dousias V, Tsanadis G, et al. Calcium levels during initiation of labor. Eur J Obstetrics Gynaecol Reprod Boil. 2004;115;17-22.

9. Calcium supplementation before LSCS in prevention and treatment of PPH due to uterine inertia. Available at www.abdirect-org/abstract /2010 $9946017 \mathrm{htm}$.

10. Adams JS, Chen H, Chum R, Ren S, Wu S, Gacad $\mathrm{M}$, et al. Substrate and enzyme trafficking as a means of regulating 1,25 dihydroxy vit $\mathrm{D}$ synthesis and action; the human innate immune response. $\mathrm{J}$ Bone Miner Res. 2007;22(Suppl 2):20-4.

11. Soloff MS, Jeng YJ, Capland JA, Strakova Z, Hoare S. Signal pathways mediating oxytocin stimulation of PG synthesis in select target cells. Experimental Physiology. 2000;85:51S-8S.

12. Driessen M, Bouvier-Colle MH, Dupont C, Khoshnood B, Rudigoz RC, Deneux-Tharaux C, et al. $\mathrm{PPH}$ resulting from uterine atony after vaginal delivery ; factors associated with severity. Obstet Gynecol. 2011;117(1);21-31.

13. Farber MK, Schultz R, Lugo L, Liu X, Huang C, et al. The effect of co-administration of IV calcium chloride and oxytocin on maternal hemodynamics and uterine tone following caesarian delivery: a double blind, randomized, placebo controlled trial. Int J Obstet Anesth. 2015;24(3):217-24.

Cite this article as: Premalahta HL, Krishnegowda R. Prospective study of association of uterine atonicity and serum calcium levels. Int J Reprod Contracept Obstet Gynecol 2016;5:2221-3. 